\title{
Pemanfaatan Video Edukasi Dalam Perbaikan Pengetahuan Gizi Pada Remaja
}

\author{
Inggita Kusumastuty ${ }^{1}$, Fajar Ari Nugroho ${ }^{1 *}$, Zunita Puri Prihandini', Anggun \\ Rindang Cempaka1, Ayuningtyas Dian Ariestiningsih', Dian Handayani1 ${ }^{1}$
}

1. Jurusan Gizi Fakultas Kedokteran Universitas Brawijaya

\begin{abstract}
ABSTRAK
Pendahuluan: Kurangnya pengetahuan menyebabkan perilaku makan yang tidak sehat pada remaja. Pemberian edukasi melalui media video terbukti dapat meningkatkan pengetahuan secara signifikan. Penelitian ini bertujuan untuk mengetahui perbedaan pengetahuan gizi sebelum dan setelah diberikan edukasi melalui video.

Metode: Desain penelitian ini adalah quasi eksperimental pada 155 siswa SMP sederajat di Kota Malang. Kegiatan dilaksanakan melalui zoom meeting dengan pemberian edukasi gizi melalui media video dengan durasi 13 menit 5 detik. Pengukuran tingkat pengetahuan melalui 10 pertanyaan pilihan ganda yang disusun dalam google form. Pengukuran dilakukan sebelum dan setelah video edukasi diberikan. Untuk mengetahui perbedaan tingkat pengetahuan sebelum dan setelah pengetahuan dilakukan analisis menggunakan uji statitik Wilcoxon Signed Ranks Test.

Hasil dan pembahasan: Penelitian ini dilakukan pada 155 siswa SMP sederajat dikota malang dimana mayoritas berjenis kelamin perempuan dan berada di kelas 8 (delapan). Rata-rata tingkat pengetahuan sebelum edukasi adalah 39.35 \pm 13.6. Setelah edukasi diberikan melalui media video terjadi peningkatan pengetahuan dengan rata-rata sebesar $65.68 \pm 21.8$. hasil Uji statistik menunjukkan $\mathrm{p} 0.000$ yang artinya terdapat perbedaan tingkat pengetahuan gizi pada remaja secara signifikan setelah diberikan edukasi melalui video.
\end{abstract}

Kesimpulan: Video edukasi gizi efektif dalam meningkatkan pengetahuan gizi pada remaja di Kota Malang.

Kata Kunci: edukasi; gizi; pengetahuan; remaja video

\begin{abstract}
Introduction: The lack of knowledge is one of the causes of unhealthy eating behavior in adolescents. Providing video education has been proven significantly increase adolescent's knowledge. This study aimed to determine the nutritional knowledge different of adolescents before and after being given nutrition educational video.

Methods: This study design is quasi-experimental that involved 155 junior high school students in Malang City. The activity was carried out through a zoom meeting by providing nutrition education video with a duration of 13 minutes 5 seconds. The measurement of knowledge level done by 10 multiple choice questions in google form. The measurements were taken before and after the educational video was given. The difference level of knowledge before and after intervention then analysed by the Wilcoxon Signed Ranks Test statistical test.

Results and discussion: This study was conducted on 155 junior high school students in the city of Malang where the majority were female and were in grade 8 (eighth). The average level of knowledge before education was 39.35 \pm 13.6. While after video education intervention, there was an increase in knowledge with an average of 65.68+21.8. The statistical analysis showed the p value 0.000. This means that there was a significant difference of level nutritional knowledge among adolescents after intervention.

Conclusion: Nutrition education video can effectively increase nutritional knowledge among adolescents in Malang City
\end{abstract}

Key words: education; nutrition; knowledge; adolescent video

Correspondence: Dr. Fajar Ari Nugroho, S.Gz, M.Kes, Jurusan Gizi Fakultas Kedokteran Universitas Brawijaya, Email : fajar_arinugroho.fk@ub.ac.id 


\section{PENDAHULUAN}

Remaja merupakan masa peralihan dari anak-anak menuju dewasa. Menurut Adriani \& Wirjatmadi (2012), masa remaja adalah waktu terjadinya perubahan yang berlangsung cepat dalam hal pertumbuhan fisik, kognitif, dan psikososial ${ }^{1}$. Perubahan fisik pada masa remaja mempengaruhi status kesehatan dan gizi ${ }^{2}$. Pada masa remaja akan mencapai pertumbuhan fisik secara maksimal ${ }^{3}$. Pada masa remaja ini perlu pemenuhan gizi untuk mengoptimalkan pertumbuhan dan perkembangannya. Penyebab masalah gizi pada remaja diantaranya pemahaman gizi yang salah, kebiasaan makan buruk dan berlebihan serta banyaknya promosi makanan tidak seimbang ${ }^{1}$. Kurangnya pengetahuan gizi menyebabkan perilaku makan remaja yang tidak sehat sehingga pemenuhan energi, zat gizi makro maupun zat gizi mikro berlebih atau kurang ${ }^{4}$. Hal ini menuntut tenaga kesehatan dalam pemberian edukasi yang tepat pada remaja. Menurut Integrated Theory of Health Behavior Change bahwa pengetahuan dan keyakinan yang berkaitan dengan kesehatan dapat meningkatkan perilaku kesehatan, terutama ketika menjadi bagian intervensi yang ditargetkan ${ }^{5}$. Intervensi edukasi tentang gizi dikalangan masyarakat masih tergolong rendah terutama remaja maka dari itu perlu diberikan edukasi untuk membentuk sikap dan perilaku baik dalam pemilihan makanan.

Berdasarkan saran penelitian Tamrin (2019) dalam mengkomunikasikan edukasi perlu memanfaatkan media yang menarik agar sasaran bersemangat dalam mengikuti kegiatan edukasi ${ }^{6}$. Menurut penelitian Aeni dan Yuhandina (2018) menyatakan bahwa responden yang diberikan edukasi baik dengan demontrasi maupun video mengalami peningkatan pengetahuan baik karena informasi yang disampaikan lebih mudah dipahami ${ }^{7}$. Pada penelitian ini edukasi diberikan dalam bentuk video dengan durasi pendek yang diharapkan menyampaikan informasi untuk meningkatkan pengetahuan gizi remaja.

Berdasarkan uraian diatas maka kegiatan penelitian ini bertujuan untuk mengetahui perbedaan pengetahuan gizi pada siswa SMP di Kota Malang sebelum dan setelah diberikan edukasi dalam bentuk video edukasi

\section{METODE}

Penelitian ini menggunakan desain Pre-Posttest Quasi Experimental. Populasi penelitian ini adalah siswa SMP di Kota Malang. Pemilihan subjek penelitian secara purposive sampling dengan pemenuhan kriteria inklusi yaitu siswa dan siswi SMP di Kota Malang. Jumlah minimum subjek penelitian adalah 50 orang berdasarkan rumus perhitungan jumlah sampel. Variabel bebas pada penelitian ini adalah pemberian edukasi gizi dalam bentuk video dan variable terikat adalah pengetahuan gizi. Kegiatan ini dilakukan pada bulan Agustus 2021 melalui zoom meeting.

Video edukasi disusun dalam durasi 13 menit 5 detik dengan materi terkait (1). pengertian remaja pada umumnya dan terjadinya pertumbuhan dan perkembangan fisik, kognitif, dan psikologi; (2). klasfikasi remaja menurut The Health Resources and Services Administrations Guidelines Amerika Serikat; (3). perilaku makan pada remaja dipengaruhi oleh 5 aspek; (4). Pengaturan makan sesuai dengan pedoman yang berlaku yaitu Pedoman Gizi Seimbang serta penerapan 4 pilar gizi seimbang; (5). tumpeng gizi seimbang; (6). pentingnya pemenuhan gizi pada remaja serta dampak tidak dilakukan pemenuhan gizi pada remaja; (7). kebutuhan energi, pembagian presentase karbohidrat, protein, dan lemak serta penerapannya melalui pembagian porsi Isi Piringku; (8). sumber makanan sesuai kebutuhan; (9). pemenuhan zat gizi mikro 
vitamin dan mineral, jumlah kebutuhan, sumber makanan, dan manfaat bagi pertumbuhan dan perkembangan remaja. Video edukasi ini telah mendapat sertifikat hak cipta dari Kementerian Hukum dan Hak Asasi Manusia no. EC00202150528 tertanggal 28 September 2021 .

Instrumen dalam pengumpulan data disusun dalam bentuk google form. Pengukuran pengetahuan berupa pertanyaan sejumlah 10 soal dengan pilihan ganda (multiple choice). Pengukuran dilakukan sebelum dan setelah edukasi diberikan. Nilai pengetahuan dalam range 0 hingga 100. Analisa data yang digunakan dalam penelitian ini adalah Wilcoxon Signed Ranks Test karena data tidak terdistribusi normal. Analisa data dilakukan menggunakan software SPSS versi 22.

Penelitian ini telah memperoleh izin etik penelitian dari Komisi Etik Penelitian Kesehatan Politeknik Kesehatan Kemenkes Malang dengan Reg.No.:224 /KEPK-POLKESMA/2021

\section{HASIL DAN PEMBAHASAN}

\section{Karakteristik Subjek Penelitian}

Subjek penelitian ini sejumlah 155 orang remaja siswa SMP sederajat di Kota Malang. Mayoritas subjek penelitian adalah perempuan (71.6\%) dan berada di kelas 8 (49\%). Secara lengkap karakteristik subjek penelitian disajika pada Tabel 1.

Tabel 1. Distribusi Responden menurut Jenis Kelamin dan Kelas

\begin{tabular}{lcc}
\hline Parameter & \multicolumn{2}{c}{ Jumlah } \\
\cline { 2 - 3 } & $\mathrm{n}$ & $\%$ \\
\hline Jenis Kelamin & & \\
$\quad$ Laki-laki & 44 & 28.4 \\
$\quad$ Perempuan & 111 & 71.6 \\
\hline Kelas & & 14.8 \\
$\quad$ Tujuh & 23 & 49.0 \\
Delapan & 76 & 36.1 \\
$\quad$ Sembilan & 56 & \\
\hline
\end{tabular}

\section{Pengetahuan Gizi}

Rata-rata nilai pre-test adalah 39.35 dan terdapat peningkatan rata-rata nilai post-test sebesar adalah 65.68 (Tabel 2). Hasil analisis statistik menggunakan uji Wilcoxon Signed Ranks Test menunjukkan hasil $\mathrm{p}=0.000(\mathrm{p}<0.05)$, artinya terdapat perbedaan pengetahuan gizi sebelum dan sesudah edukasi melalui media video.

Tabel 2. Pengetahuan Sebelum dan Setelah Edukasi Gizi

\begin{tabular}{lccccc}
\hline \multirow{2}{*}{ Pengetahuan } & \multicolumn{3}{c}{ Nilai } & \multirow{2}{*}{ Nilai $\mathrm{p}$} \\
\cline { 2 - 5 } & Minimum & Maksimum & Rata-rata & \multicolumn{1}{c}{ SD } & \\
\hline Sebelum edukasi & 10 & 80 & 39.35 & 13.6 & 0.000 \\
\hline Setelah edukasi & 20 & 100 & 65.68 & 21.8 & \\
\hline
\end{tabular}

Pengetahuan gizi merupakan pengetahuan atau pemahaman individu terkait ilmu gizi dan zat gizi. Hasil penelitian ini menunjukkan bahwa pemberian edukasi melalui video edukasi dapat meningkatkan pengetahuan gizi pada remaja di Kota Malang. Data awal (pre test) menunjukkan bahwa rata-rata nilai pengetahuan gizi remaja sebesar 39.35 yang berarti bahwa pengetahuan remaja terkait gizi masih kurang. Hal ini selaras dengan penelitian Pakhri et al (2015) di SMPN 35 Makasar, dimana mayoritas remaja memiliki pengetahuan gizi yang kurang 
sebelum diberikan edukasi ${ }^{8}$. Pengetahuan gizi yang kurang menjadi penyebab perilaku makan yang tidak sehat. Pedoman Gizi Seimbang yang tidak diterapkan dalam kehidupan, dapat menghambat pertumbuhan pada remaja. Dengan pemberian edukasi diharapkan dapat memperkuat pemahaman sehingga dapat merubah perilaku gizi remaja menjadi lebih baik.

Pemberian edukasi melalui video dengan durasi 13 menit 5 detik dalam penelitian ini cukup efektif dalam meningkatkan pengetahuan remaja dengan rata-rata peningkatan nilai sebesar 26.33. Sebagian besar pengetahuan seorang individu dipengaruhi oleh penglihatan dan pendengarannya. Pengetahuan manusia disalurkan ke dalam otak melalui indra penglihatan yaitu mata sebesar $75 \%$ hingga $87 \%$, sedangkan $13 \%$ hingga $25 \%$ melalui indra yang lain ${ }^{9}$. Perilaku dengan dasar pengetahuan yang baik akan lebih bertahan lama dibandingkan dengan perilaku tanpa dasar pengetahuan, hal ini dikarenakan perilaku tanpa dasar pengetahuan terjadi bukan atas dasar kesadaran dan kemauan diri sendiri melainkan karena paksaan atau keharusan dari luar diri sendiri ${ }^{10}$.

Berbagai media yang digunakan sebagai penunjang dan alat bantu untuk metode penyuluhan salah satunya adalah media audiovisual yang dapat memberikan stimulasi secara nyata berisi gambar gerak dan unsur suara dengan durasi waktu relatif pendek yang ditayangkan dalam bentuk video ${ }^{11}$. Pemberian edukasi berupa video menjadi salah satu pendekatan untuk menyampaikan informasi dan pesan mudah dipahami ${ }^{12}$. Menampilkan video dapat merangsang indera pendengaran dan penglihatan sehingga membuat remaja lebih cepat menerima informasi dan mengingatnya ${ }^{11}$. Hasil penelitian ini sejalan dengan penelitian Harini dan Rahmawati (2020) bahwa pemberian edukasi berupa video learning multimedia tentang menarche efektif dalam peningkatan pengetahuan pada remaja ${ }^{13}$. Penelitian lain juga menunjukkan efektifitas dari penggunaan video dalam peningkatan pemahaman remaja tentang pengetahuan HIV/AIDS dan anemia $^{14.15}$. Menampilkan video dapat merangsang indera pendengaran dan penglihatan sehingga membuat remaja lebih cepat menerima informasi dan mengingatnya.

\section{KESIMPULAN}

Pemberian edukasi melalui media edukasi berupa video pendek dapat meningkatkan pengetahuan gizi pada remaja di Kota Malang.

\section{UCAPAN TERIMA KASIH}

Terima kasih kepada Fakultas Kedokteran Universitas Brawijaya yang telah memberikan dana kegiatan pengabdian kepada masyarakat sumber PNBP FKUB TA 2021 dengan No. kontrak 3969.3/18/UN10.F08/PM/2021. Terima kasih atas kerjasama dari Dinas Kesehatan Kota Malang, Dinas Pendidikan Kota Malang dan Kementerian Agama Kota Malang dalam pelaksanaan kegiatan pengabdian masyarakat pada siswa SMP sederajat di Kota Malang.

\section{DAFTAR PUSTAKA}

1. Adriani, Wirjatmadi B. Peranan Gizi dalam Siklus Kehidupan. Prenadamedia Group; 2016.

2. Sulistyoningsinh H. Gizi untuk Kesehatan Ibu dan Anak: Palgrave Macmillan; 2012.

3. Jannah M. Remaja dan Tugas-tugas Perkembangan dalam Islam. Psikoislamedia: Jurnal Psikologi. 2017;1.

4. Pujiati A, Rahmalia S. Hubungan antara Perilaku Makan dengan Status Gizi pada Remaja Putri. JOM. 2015;2:1345-52.

5. Sari N, Ighwana B. Penggunaan mHealth Mampu Memperbaiki Perilaku Kesehatan Pasien Penyakit Tidak Menular. BIkfokes. 2020;1:57-65. 
6. Tamrin A, Lestari RS, Gizi J, Makassar K, Gizi AJ, Kesehatan P, et al. Pengetahuan dan Sikap Siswa SMP Negeri Barru. 2019;26(2012):185-9.

7. Aeni N, Yuhandini DS. Pengaruh Pendidikan Kesehatan dengan Media Video dan Metode Demonstrasi terhadap Pengetahuan SADARI. Jurnal Care. 2018;6.

8. Pakhri A, Chaerunimah RR. Edukasi Gizi terhadap Pengetahuan dan Kebiasaan Jajan pada Siswa SMP 35 Makassar. Media Gizi dan Pangan. 2018;25(1).

9. Nurcahyani AD. Intervensi Penyuluhan Gizi Seimbang dengan Media Video terhadap Perubahan Asupan Zat Gizi Remaja Putri. Yapenas. 2020;2(3):159-65.

10. Mertha IM. Pengetahuan dan Kepatuhan Kontrol Pasien Diabetes Mellitus. Skala Husada. 2015;13:165-76.

11. Azizaturrahmah N. Perbedaan Pengetahuan antara Sebelum dan Sesudah Intervensi Penyuluhan Menggunakan Media Leaflet Tentang Penyebab Dermatitis dan Pencegahannya pada Pekerja Proses Finishing Mebel Kayu di Ciputat Timur. Journal of Petrology. 2013;369(1):1689-99.

12. Septiani S, Ervina A. Hubungan Jenis Kelamin dan Sumber Informasi dengan Pengetahuan Remaja Mengenai Penyakit Menular Seksual (PMS) Susan. Obstretika. 2014;3(1):1-15.

13. Harini R, Rahmawati NA. Video Learning Multimedia Berpengaruh terhadap Pengetahuan Remaja tentang Menache. Physiotherapy and Health Science. 2021;2.

14. Damayanti A, Tyastuti S, Retnaningsih YS. Pengaruh Media Video terhadap Peningkatan Pengetahuan HIV/AID pada Remaja di SMKN 1 Temon. Repository Poltekes Jogja.

15. Putri HP, Andara F, Sufyan DL. Pengaruh Edukasi Berbasis Video terhadap Peningkatan Pengetahuan Remaja Putri di Jakarta Timur. Jurnal Bakti Masyarakat Indonesia. 2021;4. 